\title{
Physical health problems among Iraqi women with ectopic pregnancy
}

\author{
Sarah Flaieh Essa*, Hawraa Hussein Ghafel
}

Maternal and Neonate Nursing Department, College of Nursing, University of Baghdad, Baghdad, Iraq.

*Correspondence to: Sarah Flaieh Essa (E_mail: Sarra.Faleeh1203a@conursing.uobaghdad.edu.iq)

(Submitted:09 April 2021 - Revised version received: 21 April 2021 - Accepted: 04 May 2021 - Published online: 26 June 2021)

\begin{abstract}
Objective To assess physical health problems among women with ectopic pregnancy and to evaluate the levels of Physical health among women with ectopic pregnancy, and to identify demographic characteristics of ectopic pregnant women.

Methods This study was conducted at maternity hospital in Karbala city in Iraq to assess the physical health problems of women with ectopic pregnancy. This study was started in January 2020 to March 2021, The data regarding women's health problems was achieved from the patient's charts that recorded in the Statistical Department in the hospitals, the study consist of (40) women with ectopic pregnancy which were selected according to inclusion criteria (Women who had ectopic pregnancy, Women in reproductive age only). The data are analyzed through the use of descriptive and inferential statistics analysis procedures were employed for the data analysis.

Result The findings of the study exhibits that women with ectopic pregnancy were suffering from physical health problems such as (acute abdominal pain, tired and lethargic, faint, hypotension, vaginal bleeding, internal bleeding). The mean of scores for items related to physical health problems among women that show bad among most of items $(1,3,4,6,7,8$, and 9) except item 2, 5, and 6 that show fair.

Conclusion The study concludes that women with ectopic pregnancy were suffering from physical problem such as (acute abdominal pain, tired and lethargic, faint, hypotension, vaginal bleeding, and internal bleeding).

Keywords physical health problems, pregnancy, ectopic, pregnant women, Iraq
\end{abstract}

\section{Introduction}

Ectopic pregnancy (EP) falls under the gynecological emergency and/or reproductive management of women in which fertilized ovum implantation outside the endometrial cavity occurs. ${ }^{1}$ When the forming blastocyst inserts either outside the uterus fallopian tube, an ectopic pregnancy occurs: ampullary (79.6\%); isthmic (12.3\%); fimbrial (6.2\%), ovary $(0.15 \%)$ and abdominal cavity (1.4\%)] or in an irregular location inside the uterus cornual (1.9\%), cervical $(0.15 \%)$. In the fallopian tubes, the largest proportion (98.3 percent) of ectopic pregnancies occur. $^{2}$ Ectopic pregnancies may occur anywhere in the reproductive tract, with the fallopian tube being the most common location. ${ }^{3}$ The risk of an ectopic pregnancy is increased by many factors. Such risk factors share a similar mechanism of action, such as interference with the role of the Fallopian tube. In the Fallopian tube, an egg is usually fertilized and then moves down the tube to the implantation site. Any mechanism that interferes during this phase with the normal function of the fallopian tube raises the risk of ectopic pregnancy. The mechanism can be anatomical e.g. scarring that blocks the egg's transport or functional e.g. Impaired mobility of tubal. ${ }^{4}$ Clearly, the cause of ectopic pregnancy is not known, but some risk factors that increase the incidence of ectopic pregnancy include: advanced maternal age (over 35 years of age). Chronic inflammatory disorder in the pelvis. The prior ectopic pregnancy history. Previous surgical history to the fallopian tube or nearby structure. Intrauterine contraceptive (IUD) products and hormonal drug overdoses to induce ovulation. ${ }^{5}$ While typical signs and symptoms of pregnancy may occur and the results of a pregnancy test may be positive, an ectopic pregnancy cannot proceed as normal. To help diagnose a possible ectopic pregnancy, the following signs can be used: painful or stabbing pain that can come and go and differ in severity. (Because of blood pooling under the diaphragm from a ruptured ectopic pregnancy, the pain can be in the pelvis, abdomen, or even the shoulder and neck). Heavier or lighter vaginal bleeding than usual, gastrointestinal symptoms, fatigue or dizziness, and fainting. ${ }^{6}$

\section{Materials and Methods}

This study was conducted at maternity hospitals in Karbala city to assess the physical health of women with ectopic pregnancy. This study was started in from the $1^{\text {st }}$ of January 2020 to $1^{\text {st }}$ of March 2021, the data regarding rate women's with ectopic pregnancy was achieved from the data recorded in the Statistical Department in the hospitals. A descriptive study was non-probability (a purposive sample) the study consist of (40) women with ectopic pregnancy which were selected according to inclusion criteria that are (women who had ectopic pregnancy, women in reproductive age only). This questionnaire was composed of three parts, part one: consists of sections that are related socio-demographic characteristics include (age, educational level, women occupation, residency, and smoking). Part two include: reproductive status history, Previous medical history, The Previous history of gynecological diseases, previous surgical history). Part three include: physical domain, reliability of questionnaire is determined through a pilot study and validity through panel (13) experts. Descriptive statistical analysis and inferential statistical analysis procedures were employed for the data analysis.

\section{Results}

Table 1 shows that women are with age $29 \pm 7$ years in which the highest percentage is refer to $23-27$ years $(32.5 \%)$. It have been found (32.5\%) of women are with age group 23-27 years, they are read and write as reported with high percentage of 


\begin{tabular}{|c|c|c|c|c|}
\hline List & Characteristics & & $f$ & $\%$ \\
\hline \multirow[t]{7}{*}{1} & \multirow{7}{*}{$\begin{array}{l}\text { Age } \\
(M \pm S D=29 \pm 7)\end{array}$} & $13-17$ year & 2 & 5 \\
\hline & & $18-22$ year & 3 & 7.5 \\
\hline & & $23-27$ year & 13 & 32.5 \\
\hline & & 28 - 32 year & 7 & 17.5 \\
\hline & & 33 - 37 year & 11 & 27.5 \\
\hline & & $38 \leq$ year & 4 & 10 \\
\hline & & Total & 40 & 100 \\
\hline \multirow[t]{4}{*}{2} & \multirow[t]{4}{*}{ Residency } & Urban & 29 & 72.5 \\
\hline & & Rural & 10 & 25 \\
\hline & & Suburban & 1 & 2.5 \\
\hline & & Total & 40 & 100 \\
\hline \multirow[t]{7}{*}{3} & \multirow[t]{7}{*}{ Level of education } & $\begin{array}{l}\text { Doesn't read \& } \\
\text { write }\end{array}$ & 3 & 7.5 \\
\hline & & Read \& write & 14 & 35 \\
\hline & & Primary school & 13 & 32.5 \\
\hline & & $\begin{array}{l}\text { Intermediate } \\
\text { school }\end{array}$ & 6 & 15 \\
\hline & & $\begin{array}{l}\text { Secondary } \\
\text { school }\end{array}$ & 1 & 2.5 \\
\hline & & $\begin{array}{l}\text { Institute/ } \\
\text { college + }\end{array}$ & 3 & 7.5 \\
\hline & & Total & 40 & 100 \\
\hline \multirow[t]{4}{*}{4} & \multirow[t]{4}{*}{ Occupation } & Employee & 9 & 22.5 \\
\hline & & Housewife & 30 & 75 \\
\hline & & Students & 1 & 2.5 \\
\hline & & Total & 40 & 100 \\
\hline \multirow[t]{3}{*}{5} & \multirow[t]{3}{*}{ Smoking } & No & 36 & 90 \\
\hline & & Yes & 4 & 10 \\
\hline & & Total & 40 & 100 \\
\hline
\end{tabular}

f, Frequency; \%, Percentage; M, Mean; SD, Standard deviation.

$35 \%$ and $32.5 \%$ of them are graduated from primary school; (75\%) of women are housewives and only $22.5 \%$ of them are governmental employee, $(72.5 \%)$ are resident in urban. The women show bad levels of physical health (55\%), There is significant relationship among physical health among women with ectopic pregnancy with their age. No significant relationship among physical health among women with ectopic pregnancy with respect to their level of education, occupational status, residence area.

Table 2 displays the mean of scores for items related to physical health problems among women that show bad among most of items $(1,3,4,6,7,8$, and 9) except item 2,5 , and 6 that show fair.

\section{Discussion}

Table 1 shows that the socio-demographic characteristics of women with ectopic pregnancy high percentage (32.5\%) of women are with age group 23-27 years old. Such finding was

\begin{tabular}{|c|c|c|c|c|c|}
\hline List & Items & Responses & $f(\%)$ & M.S & Assessment \\
\hline \multirow[t]{3}{*}{1} & \multirow{3}{*}{$\begin{array}{l}\text { Severe and } \\
\text { recurring } \\
\text { stomach } \\
\text { pain }\end{array}$} & Never & 37 (92.5) & \multirow[t]{3}{*}{1.08} & \multirow[t]{3}{*}{ Bad } \\
\hline & & Sometimes & $3(7.5)$ & & \\
\hline & & Always & $0(0)$ & & \\
\hline \multirow[t]{3}{*}{2} & \multirow{3}{*}{$\begin{array}{l}\text { Pain in the } \\
\text { shoulder area }\end{array}$} & Never & $16(40)$ & \multirow[t]{3}{*}{1.95} & \multirow[t]{3}{*}{ Fair } \\
\hline & & Sometimes & $10(25)$ & & \\
\hline & & Always & $14(35)$ & & \\
\hline \multirow[t]{3}{*}{3} & \multirow{3}{*}{$\begin{array}{l}\text { Tired and } \\
\text { lethargic }\end{array}$} & Never & 33 (82.5) & \multirow[t]{3}{*}{1.23} & \multirow[t]{3}{*}{ Bad } \\
\hline & & Sometimes & $5(12.5)$ & & \\
\hline & & Always & $2(5)$ & & \\
\hline \multirow[t]{3}{*}{4} & \multirow[t]{3}{*}{ Dizzy } & Never & $23(57.5)$ & \multirow[t]{3}{*}{1.63} & \multirow[t]{3}{*}{ Bad } \\
\hline & & Sometimes & $9(22.5)$ & & \\
\hline & & Always & $8(20)$ & & \\
\hline \multirow[t]{3}{*}{5} & \multirow[t]{3}{*}{ Faint } & Never & $14(35)$ & \multirow[t]{3}{*}{2.25} & \multirow[t]{3}{*}{ Fair } \\
\hline & & Sometimes & $2(5)$ & & \\
\hline & & Always & $24(60)$ & & \\
\hline \multirow[t]{3}{*}{6} & \multirow{3}{*}{$\begin{array}{l}\text { Nauseous } \\
\text { and vomiting }\end{array}$} & Never & $13(32.5)$ & \multirow[t]{3}{*}{1.95} & \multirow[t]{3}{*}{ fair } \\
\hline & & Sometimes & $16(40)$ & & \\
\hline & & Always & 11 (27.5) & & \\
\hline \multirow[t]{3}{*}{7} & \multirow{3}{*}{$\begin{array}{l}\text { Severe drop } \\
\text { in blood } \\
\text { pressure }\end{array}$} & Never & 25 (62.5) & \multirow[t]{3}{*}{1.53} & \multirow[t]{3}{*}{ Bad } \\
\hline & & Sometimes & $9(22.5)$ & & \\
\hline & & Always & $6(15)$ & & \\
\hline \multirow[t]{3}{*}{8} & \multirow{3}{*}{$\begin{array}{l}\text { Vaginal } \\
\text { bleeding }\end{array}$} & Never & $25(62.5)$ & \multirow[t]{3}{*}{1.65} & \multirow[t]{3}{*}{ Bad } \\
\hline & & Sometimes & $4(10)$ & & \\
\hline & & Always & $11(27.5)$ & & \\
\hline 9 & Internal & Never & $29(72.5)$ & 1.55 & Bad \\
\hline & Dleeding & Sometimes & $11(27.5)$ & & \\
\hline & & Always & $0(0)$ & & \\
\hline
\end{tabular}

f, Frequency; \%, Percentage; M.S, Mean of score; Bad, 1 - 1.66; Fair, $1.67-2.33$; Good, $2.34-3$.

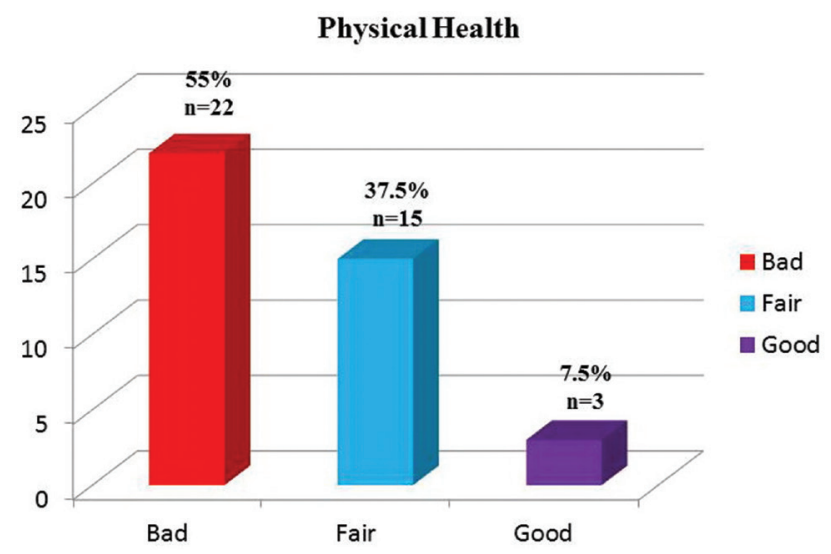

Fig. 1 Levels of physical health among women with ectopic Pregnancy $(N=40)$. This figure reveals that $55 \%$ of women are showing bad physical health level. 
supported by the study of $\mathrm{Li}$ and others who found in their study that the highest percentage of women with ectopic pregnancy among (15-24) years old $(50.6 \%)^{7}$. Table 1 revealed that they are resident in urban are $(72.5 \%),(25 \%)$ are resident in rural and only $(2.5 \%)$ are resident in sub-urban. This finding are not agree with study for Negewo and others (2019), who found that most of the sample was resident in Rural 58.2\%. ${ }^{8}$ With respect to their education, the study findings indicate that most of these women with ectopic pregnancy are Read \& write $(35 \%)$ (Table 1). Such result does agree with a report has indicated that more than half $(57.14 \%)$ of women with ectopic pregnancy reported Majority of patients had lower educational level. ${ }^{9}$ With regard to the women's employment, the study has revealed that (75\%) of the study sample are Housewife. These finding are supported by the study of ${ }^{10}$ who found that most of sample was housewives $55.9 \%$. Table 1 showed that high percentage $(90 \%)$ of women are None smoker such finding was supported by the $\mathrm{Li}$ and others who found in their study that the highest percentage of women with ectopic pregnancy were not smoking $(95.31 \%)^{11}$. Figure 1 exhibits that women are associated with bad physical health level (55\%) and $37.5 \%$ are with fair physical level. This study agree with study ${ }^{12}$ who found that The most common presenting symptoms were abdominal pain (94\%), abnormal vaginal bleeding (74\%) and amenorrhoea (64\%). Cervical excitation (86\%) and adnexal tenderness (84\%) were frequent pelvic findings and an adnexal mass was noted in $27 \%$ of patients.

Table 2 presented the sub-domain of biological health among women with ectopic pregnancy the finding showed that women having bad level of severe and recurring stomach pain $(92.5 \%)$, tired and lethargic (82.5\%), dizzy (57.5\%), severe drop in blood pressure $(62.5 \%)$, vaginal bleeding $(62.5 \%)$, and internal bleeding $(72.5 \%)$, and having fair level of pain in the shoulder area $(40 \%)$, faint $(35 \%)$, nauseous and vomited (32.5\%). The study provided supportive evidence for current findings that found (Orazulike \& Konje, 2013) that report a presence of physical problem among their sample. ${ }^{13}$ Nausea and breast soreness are common symptoms in both ectopic pregnancy and more common symptoms in ectopic pregnancy and can indicate a medical emergency such as sharp waves of pain in the abdomen, pelvis, shoulder, or neck, severe pain that occurs on one side of the abdomen, light to heavy vaginal spotting or bleeding, dizziness or fainting and finally rectal pressure Wakankar and Kedar (2015) in their study concluded that the pain was in $86.53 \%$ women, amenorrhea and bleeding per vagina are mostly occurring in ectopic pregnancy. ${ }^{14}$

\section{Conclusion}

The study concludes that women with ectopic pregnancy were suffering from physical health problems such as (acute abdominal pain, tired and lethargic, faint, hypotension, vaginal bleeding, and internal bleeding).

\section{Conflicts of Interest}

None.

\section{References}

1. Abdulkareem, T., A. \& Eidan S., M. (2017). Ectopic Pregnancy: Diagnosis, Prevention and Management. Research Gate.

2. Soren, M., Patnaik R., \& Sarangi B. k. (2017). A clinical study on ectopic pregnancy International Journal of Research in Medical Sciences. 5(11):4776-4782.

3. Husmo C., \& Drahonovsky. (2008). Ectopic Pregnancy - Etiology, modern diagnostics and therapeutic approach. Dissertation in PreventiveMedicine

4. Tenore, J. ( 2000). Ectopic Pregnancy. Journal of the American Academy of Family Physicians. 61(4):1080-1088

5. Saudi German Hospitals Group. (2019). 6 Risk factors for ectopic pregnancy. Retrieved from https://www.sghgroup.com.sa/en/medical-blog/6-riskfactors-ectopic-pregnancy.

6. American Pregnancy Association. (2020). Ectopic Pregnancy. Retrieved from https://americanpregnancy.org/healthy-pregnancy/pregnancycomplications/ectopic-pregnancy-839.

7. Li, C., Meng, C. X., Zhao, W. H., Lu, H. Q., Shi, W., \& Zhang, J. (2014). Risk factors for ectopic pregnancy in women with planned pregnancy: a case-control study. European Journal of Obstetrics \& Gynecology and Reproductive Biology, 181:176-182.

8. Negewo, A.,N., Feyissa, G., T., Diriba, G., Gemeda, D., H., and Kebede, A., (2019). Prevalence and Management Outcome of Ectopic Pregnancy in Adama Hospital Medical College, East Shoa Zone, Oromia Region, Ethiopia. EC Gynaecology 8.9 (2019): 844-850.

9. Mahmood MK. Ectopic Pregnancy; Causes and Management in Kerbala Maternity Hospital. Karbala Journal of Medicine. 2019;12(2).

10. Thonneau P, Hijazi Y, Goyaux N, Calvez T, Keita N. Ectopic pregnancy in Conakry, Guinea. Bulletin of the World Health Organization. 2002;80:365-70.

11. Li C, Zhao WH, Zhu Q, Cao SJ, Ping H, Xi X, Qin GJ, Yan MX, Zhang D, Oiu J, Zhang J. Risk factors for ectopic pregnancy: a multi-center case-control study. BMC pregnancy and childbirth. 2015;15(1):1-9.

12. Rasheed S, Abdelmonem A, Amin M. Adolescent pregnancy in upper Egypt. International Journal of Gynecology \& Obstetrics. 2011;112(1):21-4.

13. Orazulike NC, Konje JC. Diagnosis and management of ectopic pregnancy. Women's Health. 2013;9(4):373-85.

14. Udigwe GO, Umeononihu OS, Mbachu II. Ectopic pregnancy: a 5 year review of cases at nnamdi azikiwe university teaching hospital (NAUTH) Nnewi. Nigerian Medical Journal. 2010;51(4):160. 